\title{
PUSAT KESENIAN DAYAK KALIMANTAN BARAT DI KOTA PONTIANAK
}

\author{
Hendrikus Trivaldo ${ }^{1}$, Uray Fery Andi ${ }^{2}$, Rudiyono ${ }^{3}$ \\ ${ }^{1}$ Program Studi Arsitektur, Fakultas Teknik, Universitas Tanjungpura \\ hendrikustrivaldo@gmail,com \\ ${ }^{2}$ Program Studi Arsitektur, Fakultas Teknik, Universitas Tanjungpura \\ ${ }^{3}$ Program Studi Arsitektur, Fakultas Teknik, Universitas Tanjungpura
}

Naskah diajukan pada: 1 Februari 2021

Naskah revisi akhir diterima pada: 2 Februari 2021

\begin{abstract}
Abstrak
Kalimantan Barat merupakan Provinsi yang memiliki potensi kesenian yang sangat beragam. Provinsi Kalimantan Barat dihuni oleh penduduk asli dan kaum pendatang lainnya. Suku bangsa yang dominan besar yaitu Dayak, Melayu dan Tionghoa. Suku Dayak kaya akan keberagaman kesenian, seperti seni tari, seni pahat, seni lukis dan lain-lain. Setiap tahun, suku Dayak mengadakan Gawai Dayak yang menampilkan perlombaan kesenian Dayak. Kesenian Dayak dikembangkan oleh sanggar-sanggar seni yang jumlahnya cukup banyak namun belum terorganisir dengan baik, sehingga butuh sebuah wadah berupa Pusat Kesenian Dayak Kalimantan Barat. Tujuan dari perancangan Pusat Kesenian Dayak Kalimantan Barat di Kota Pontianak yaitu menghasilkan rancangan pusat kesenian Dayak Kalimantan Barat di Kota Pontianak sebagai wadah yang memfasilitasi kesenian Dayak di Kalimantan Barat yang mencerminkan ciri khas Dayak di Kalimantan Barat. Metode perancangan yang digunakan pada Perancangan Pusat Kesenian Dayak Kalimantan Barat di Kota Pontianak terdiri dari beberapa tahapan yaitu tahap gagasan dan tahap pengumpulan data terkait kebutuhan perancangan dan lokasi perancangan. Hasil perancangan Pusat Kesenian Dayak Kalimantan Barat di Kota Pontianak yaitu dapat memfasilitasi kesenian Dayak Kalimantan Barat bersarkan fungsi edukasi, informasi, promosi dan rekreasi yang dapat menunjang kegiatan kesenian Dayak Kalimantan Barat serta dapat menampilkan bentuk yang mencerminkan ciri khas arsitektur Dayak Kalimantan Barat.
\end{abstract}

Kata-kata Kunci: Dayak, Pusat Kesenian, Kesenian Dayak, Kalimantan Barat

\begin{abstract}
West Kalimantan is a province that has a very diverse artistic potential. West Kalimantan Province inhabited by indigenous people and other migrants. The dominant ethnic groups are Dayak, Malay and Chinese. The Dayak tribe is rich in a variety of arts, such as dance, sculpture, painting and others. Every year, the Dayak tribe holds a Dayak Gawai featuring a Dayak art competition. Dayak art was developed by a large number of art studios but not yet well-organized, so a forum for the Dayak Arts Center of West Kalimantan was needed. The purpose of designing the West Kalimantan Dayak Arts Center in Pontianak City is to produce a design for the Dayak arts center of West Kalimantan in Pontianak City as a forum that facilitates Dayak arts in West Kalimantan that reflects the characteristics of Dayak in West Kalimantan. The design method used in the Design of the Dayak Arts Center in West Kalimantan in Pontianak City consists of several stages, namely the idea stage and the data collection stage related to the design needs and the design location. The design result of the West Kalimantan Dayak Arts Center in Pontianak City is to facilitate West Kalimantan Dayak arts based on the functions of education, information, promotion and recreation which can support the activities of West Kalimantan Dayak arts and can display forms that reflect the characteristics of West Kalimantan Dayak architecture.
\end{abstract}

Keywords: Dayak, Arts Center, Dayak Arts, West Kalimantan 


\section{Pendahuluan}

Dayak atau Daya adalah kumpulan berbagai sub etnis Austronesia yang dianggap sebagai penduduk asli yang mendiami Pulau Kalimantan, lebih tepat lagi adalah yang memiliki budaya sungai. Hampir semua nama sebutan orang Dayak mempunyai arti sebagai sesuatu yang berhubungan dengan "perhuluan" atau sungai, terutama pada nama-nama rumpun dan nama kekeluargaannya. Kelompok Suku Dayak, terbagi dalam sub-sub suku yang kurang lebih jumlahnya 405 sub (menurut Lontaan, 1975). Masa lalu masyarakat yang kini disebut Dayak, mendiami daerah pesisir pantai dan sungai-sungai di tiap pemukiman mereka.

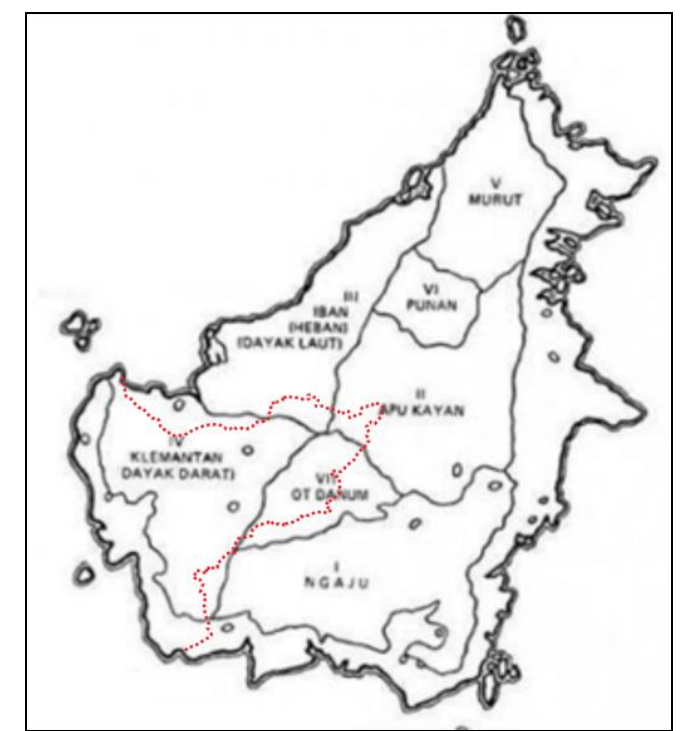

Gambar 1. Peta Persebaran Suku Dayak Sumber: Riwut, 1979

Dalam suku Dayak, ada banyak sekali kesenian yang dapat kita jumpai. Yang sangat terkenal adalah pada seni tari dan seni musik yang sangat khas. Dalam pusat kesenian Dayak Kalimantan Barat di Kota Pontianak ini, diharapkan mampu sebagai area pertunjukan bagi kesenian-kesenian yang ada pada suku Dayak Kalimantan Barat. Suku Dayak kaya akan keberagaman kesenian yang dimilikinya, seperti dalam seni tari, seni pahat, seni lukis dan kesenian lainnya. Salah satunya adalah setiap tahunnya, hampir disetiap sub suku Dayak merayakan sebuah acara Gawai Dayak yang mengadakan perlombaanperlombaan kesenian suku Dayak. Saat ini di Kalimantan Barat khususnya di Kota Pontianak, telah terdapat lembaga yang bergerak melestarikan kesenian Dayak. Namun lembaga ini hanya berkonsentrasi pada kegiatan tahunan saja, sehingga belum bisa menampilkan kesenian Dayak untuk menjadi pusat wisata suku Dayak di Kalimantan Barat, karena belum terciptanya sebuah wadah yaitu pusat kesenian.

\section{Kajian Pustaka}

Suku Dayak (Ejaan Lama: Dajak atau Dyak) adalah nama yang oleh penjajah diberi kepada penghuni pedalaman pulau Borneo yang mendiami Pulau Kalimantan (Brunei, Malaysia yang terdiri dari Sabah dan Sarawak, serta Indonesia yang terdiri dari Kalimantan Barat, Kalimantan Timur, Kalimantan Tengah, Kalimantan Utara, dan Kalimantan Selatan). Dahulu, budaya masyarakat Dayak adalah Budaya maritim atau bahari. Hampir semua nama sebutan orang Dayak mempunyai arti sebagai sesuatu yang berhubungan dengan "perhuluan" atau sungai, terutama pada nama-nama rumpun dan nama kekeluargaannya (Lontaan, 1975). Suku Dayak di Kalimantan Barat memiliki lima rumpun besar dari dari 6 suku besar yang ada di Kalimantan Barat. Lima suku besar yang ada di 
Kalimantan Barat ini yaitu Apokayan (Kenyah-Kayan-Bahau), Ot Danum - Ngaju, Iban, Klemantan dan Punan. Dari kelima suku besar dayak tersebut, di Kalimantan Barat terbagi menjadi 151 sub suku dan dari sub suku tersebut terdapat beberapa sub suku yang memiliki pembagian sub-sub suku lagi (Alloy, 2008).

Suku Dayak Kalimantan Barat memiliki kesenian yang sangat beragam. Kesenian tersebut biasanya dilakukan masyarakat Dayak dalam ritual adat, hiburan serta untuk mengisi waktu luang. Pada setiap tahun Kesenian Dayak yang ada di Kalimantan Barat ini ditampilkan dalam bentuk perlombaan pada acara Pekan Gawai Dayak di Kota Pontianak yang dilaksanakan oleh Sekberkesda Kota Pontianak. Kesenian yang diperlombakan yaitu tato, lagu dayak dewasa, menganyam manik, sape', melukis perisai, tari dayak kreasi, memahat/membuat patung dan sastra lisan (Maryani, 2018).

Arsitektur Dayak Kalimantan barat sangat beraneka ragam. Setiap Daerah yang ada di Kalimantan Barat memiliki ciri khas sendiri baik dari fasad, tata ruang dan fungsinya. Perancangan ini mengambil satu arsitektur tradisional berupa rumah betang yang berada di Kabupaten Landak. Rumah betang ini yaitu Rumah Radakng Saham yang merupakan rumah betang atau rumah Panjang Suku Dayak Kanayatn yang berada di Dusun Saham, Desa Saham, Kecamatan Sengah Temila, Kabupaten Landak. Hal ini dikarenakan suku Dayak Kanayatn merupakan suku yang Dominan di Kalimantan Barat berdasarkan data Keberagaman suku Dayak Kalimantan Barat (Alloy, 2008).

\section{Metode}

Metode perancangan yang digunakan pada perancangan Pusat Kesenian Dayak Kalimantan Barat di Kota Pontianak adalah metode perancangan oleh J. C. Jones (Nuraini dan Sudrajat, 2010). Metode ini terdiri dari beberapa tahapan yang dimulai dari tahap gagasan sebagai penentu judul perancangan dilengkapi dengan berbagai informasi untuk memperkuat gagasan seperti latar belakang dan permasalahan. Tahap selanjutnya yaitu tahap pengumpulan data terkait kebutuhan perancangan dan lokasi perancangan melalui studi literatur, studi banding, aturan, norma, serta standar yang berlaku. Setelah data terkumpul dilanjutkan dengan tahap analisis. Tahap analisis yaitu merangkum data yang telah diperoleh untuk diolah agar menemukan konsep dari analisis tersebut. Tahap selanjutnya adalah tahap sintesis yaitu berupa penarikan hasil kesimpulan dari analisis yang telah dilakukan sebelumnya berupa konsep perencanaan dan perancangan yang akan dijadikan pedoman dalam proses perancangan yang dijelaskan dalam bentuk sketsa dan gambar. Tahap selanjutnya pada hasil konsep perencanaan dan perancangan dievalusi pada tahap sintesis, untuk mengetahui kekurangan yang perlu diperbaiki. Tahap terakhir pada metode perancangan ini yaitu optimalisasi, dimana setelah mengevaluasi kekurangan pada konsep perencanaan dan perancaaan sebelumnya akan dioptimalkan dalam perancangan.

\section{Hasil dan Pembahasan}

\section{Lokasi Perancangan}

Lokasi perancangan yang dipilih sebagai lokasi Pusat Kesenian Dayak Kalimantan Barat di Kota Pontianak yaitu berada di jalan Ampera, Kelurahan Sungai Jawi, Kecamatan Pontianak Kota, Kota Pontianak. Lokasi ini berada di Kawasan Pendidikan dan berdekatan dengan kampus IKIPPGRI Pontianak. Luas Site $\pm 20.000 \mathrm{~m}^{2}$, lebar Jalan Ampera 6 m, lebar Jalan Kampus IKIP-PGRI 4 $\mathrm{m}$, koefisien dasar bangunan (KDB) 60\%, koefisien lantai bangunan (KLB) 1.8, jenis jalan yaitu jalan lokal sekunder. Batas kawasan sebelah utara yaitu lahan kosong, timur yaitu permukiman dan lahan kosong, selatan yaitu jalan Ampera dan permukiman dan sebelah barat kampus IKIP-PGRI Pontianak. GSB jalan Ampera yaitu 0,5 x 6 (lebar jalan) $+1=4$ meter. Total Luas Bangunan pada Kawasan $60 \%$ x 20.000 yaitu $12.000 \mathrm{~m}^{2}$. Luas ruang terbuka hijau $40 \%$ x $20.000 \mathrm{~m}^{2}$ yaitu $8.000 \mathrm{~m}^{2}$. Koefisien lantai bangunan $\left(1.8 \times 16.000 \mathrm{~m}^{2}\right): 9.600 \mathrm{~m}^{2}(\mathrm{KDB})$ yaitu 3 Lantai. 


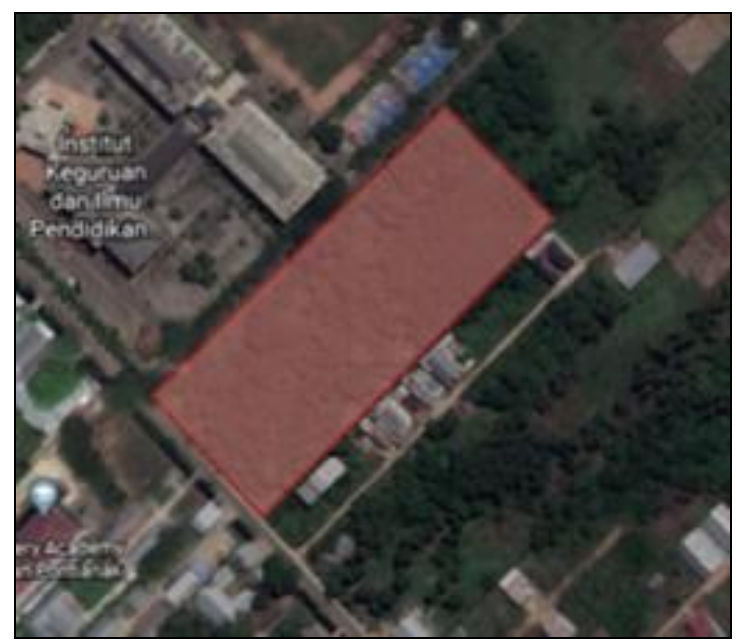

Gambar 2. Lokasi Perancangan

Sumber: Penulis, 2020

\section{Fungsi}

Fungsi perancangan Pusat Kesenian Dayak Kalimanatan Barat di Kota Pontianak yaitu mewadahi kegiatan kesenian yang berfungsi sebagai sarana edukasi, informasi, promosi dan rekreasi serta pengelola. Dari analisis tersebut Konsep fungsi yang akan diterapkan pada pusat kesenian ini yaitu sebagai tempat berkumpulnya para seniman untuk berkarya dan mengekspresikan ide-ide yang kreatif dan dapat dinikmati sebagai sebua karya seni yang indah. Berfungsi sebagai sebuah Kawasan yang terbuka untuk umum dengan unsur edukatif, informatif dan rekreatif yang berhubungan dengan kesenian suku Dayak yang ada di Kalimantan Barat.

\section{Ide \& Tema Perancangan}

Tema perancangan perancangan Pusat Kesenian Dayak Kalimantan Barat di Kota Pontianak ini yaitu menggunakan tema arsitektur tradisional Dayak. Rumah tradisional ini yaitu Rumah Radakng Saham dari suku Dayak Kanayatn yang merupakan suku Dayak dari sub-suku Klemantan. Sub-suku Dayak Klemantan merupakan suku Dayak yang dominan di Kalimantan Barat. Untuk menerapkan arsitektur tradisional Dayak, maka ide dasar yang dipakai yaitu mengambil nilai-nilai, prinsip atau makna dari arsitektur tradisional Dayak Kanayatn yaitu pada Rumah Radakng Saham yang kemudian transformasikan kedalam bentuk bangunan, tata dan pola ruang, struktur bangunan, material bangunan dan ornamen.

\section{Konsep Program Ruang}

Berdasarkan analisis kebutuhan ruang, berikut ini merupakan konsep program ruang yang dibagi berdasarkan fungsi.

Tabel 1. Program Ruang

\begin{tabular}{llllll}
\hline No. & Fungsi & Nama Ruang & & & \\
\hline 1. & Edukasi & -Parkiran & -R. Koleksi & -R. Alat & -Toilet \\
\cline { 3 - 6 } & & -Lobby & -R. Bahan & -R. Rapat & -Perpustakaan \\
\cline { 3 - 6 } & & -R. Latihan & -Galeri & -Cafetaria & \\
\cline { 3 - 6 } & & -R. Workshop & -R. Tamu & -Sekretariat Sanggar \\
\hline 2. & Informasi & -Parkiran & -Lobby & -R. Informasi & Cafetaria \\
\cline { 3 - 6 } & & - -Toilet & & & \\
\hline 3. & Promosi & -Parkiran & -Lobby & -Galeri & -R. Administrasi \\
\cline { 3 - 6 } & & -R. Koleksi & -R. Rapat & -R. Tamu & -Cafetaria \\
\hline 4. & Rekreasi & -Parkiran & -Lobby & -R. Pertunjukan & -Taman \\
\hline & & & 57 & &
\end{tabular}




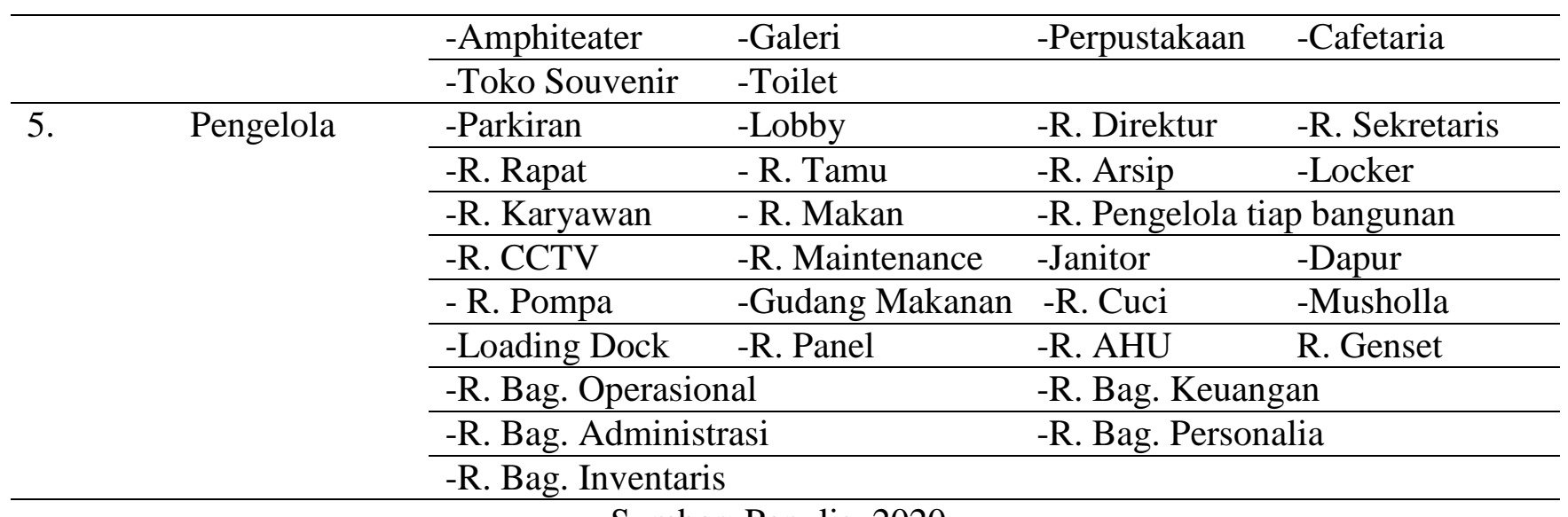

Sumber: Penulis, 2020

\section{Konsep Tapak}

Konsep tapak di dalam perancangan Pusat Kesenian Dayak Kalimanatan Barat di Kota Pontianak terbagi menjadi 5 kategori yaitu Perletakan, Orientasi, Sirkulasi, Vegetasi dan Zonasi. Konsep perletakan diperoleh berdasarkan analisis perletakan. Konsep perletakan mempertimbangkan peraturan dan tata ruang Rumah Radakng Saham.

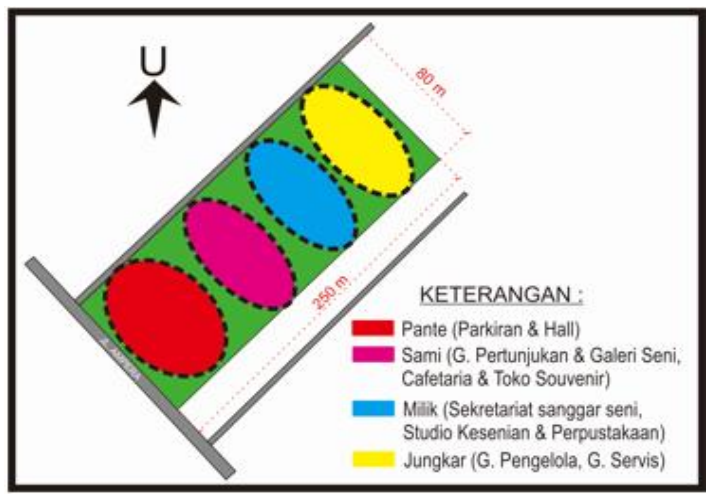

Gambar 3. Konsep Perletakan

Sumber: Penulis, 2020

Konsep orientasi yaitu bangunan mengarah kepada jalan Ampera memanfaatkan potensi jalan utama sebagai arah pandang utama. Sedangkan arah hadap alternatif yaitu menghadap ke bagian tengah kawasan yaitu ruang pertunjukan yang diharapkan menjadi pusat perhatian pada kawasan pusat kesenian ini.

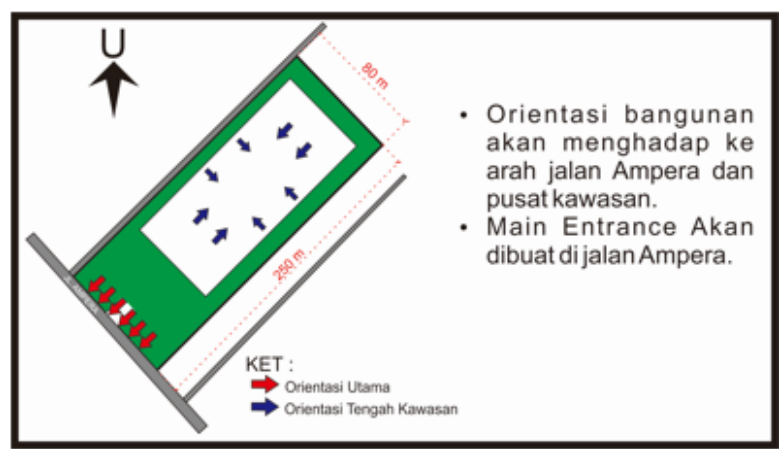

Gambar 4. Konsep Orientasi

Sumber: Penulis, 2020 
Konsep sirkulasi didapat berdasarkan analisis sirkulasi. Pintu masuk dan keluar site berada di depan site dekat jalan Ampera karena merupakan akses satu-satunya menuju site. Pada kawasan pusat kesenian ini terdapat juga sirkulasi untuk pengelola dan servis.

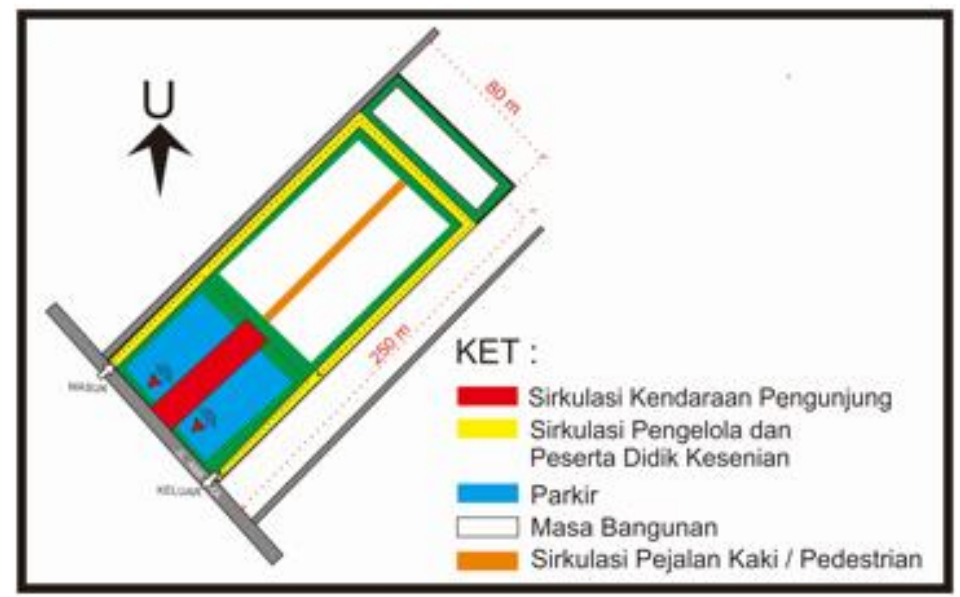

Gambar 5. Konsep Sirkulasi

Sumber: Penulis, 2020

Konsep vegetasi didapatkan berdasarkan analisis vegetasi. Vegetasi yang digunakan yaitu vegetasi peneduh, vegetasi pengarah dan vegetasi peredam kebisingan dan polusi. Pada bagian barat vegetasi pengarah dan peneduh yaitu menggunakan pohon pucuk merah. Pada bagian entrance menggunakan vegetasi peredam kebisingan yaitu cemara norfolk. Pengarah sirkulasi menggunakan vegetasi berupa pohon palem dan bambu hias.

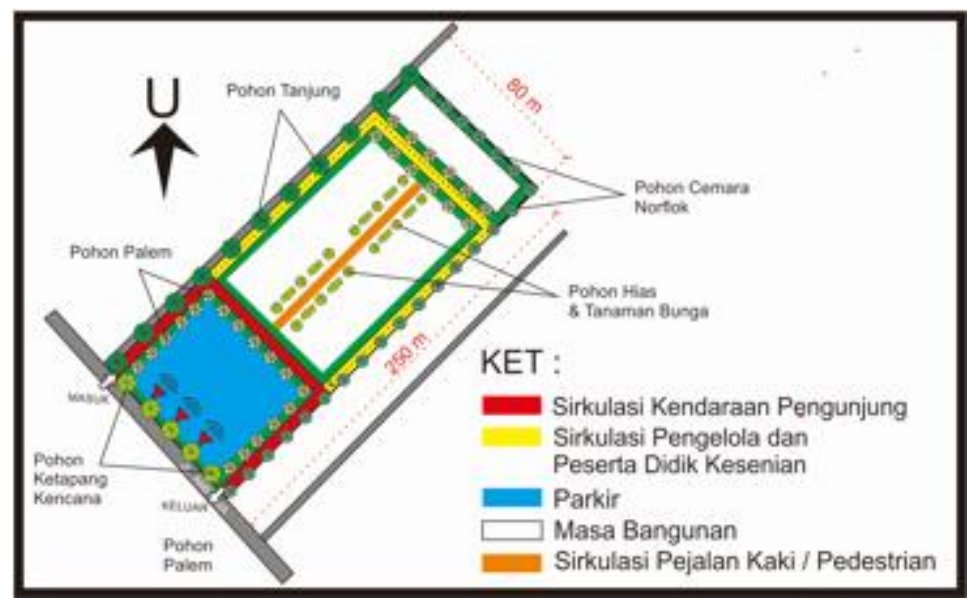

Gambar 6. Konsep Vegetasi

Sumber: Penulis, 2020

Konsep Zonasi didapat berdasarkan analisis zonasi. Konsep zonasi merupakan peruntukan ruang di dalam site mempertimbangkan sifat ruang dan konsep perancangan. Konsep Zonasi menerapkan tata ruang Rumah Radakng Saham yang terdiri dari pante atau zona publik, sami atau zona semi publik, milik atau zona privat, jungkar atau zona servis. 


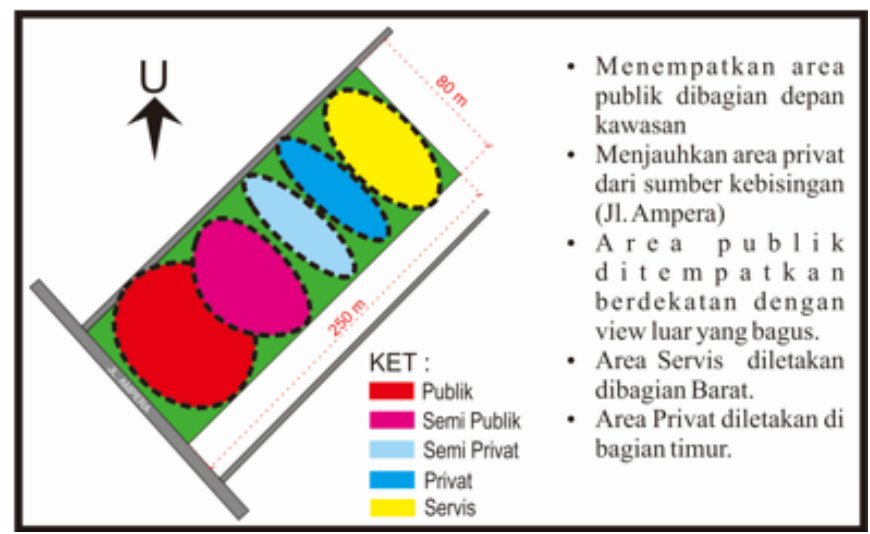

Gambar 7. Konsep Zonasi

Sumber: Penulis, 2020

\section{Konsep Bentuk}

Gubahan bentuk pada perancangan pusat kesenian ini mengacu pada tema yaitu arsitektur tradisional Dayak yang mengambil bangunan vernakular dari suku Dayak Kanayatn yaitu Rumah Radakng Saham. Gubahan bentuk dibuat berdasarkan pola tata ruang dan elemen arsitektur. Gubahan Bentuk pusat Kesenian ini dapat dilihat pada gambar berikut.

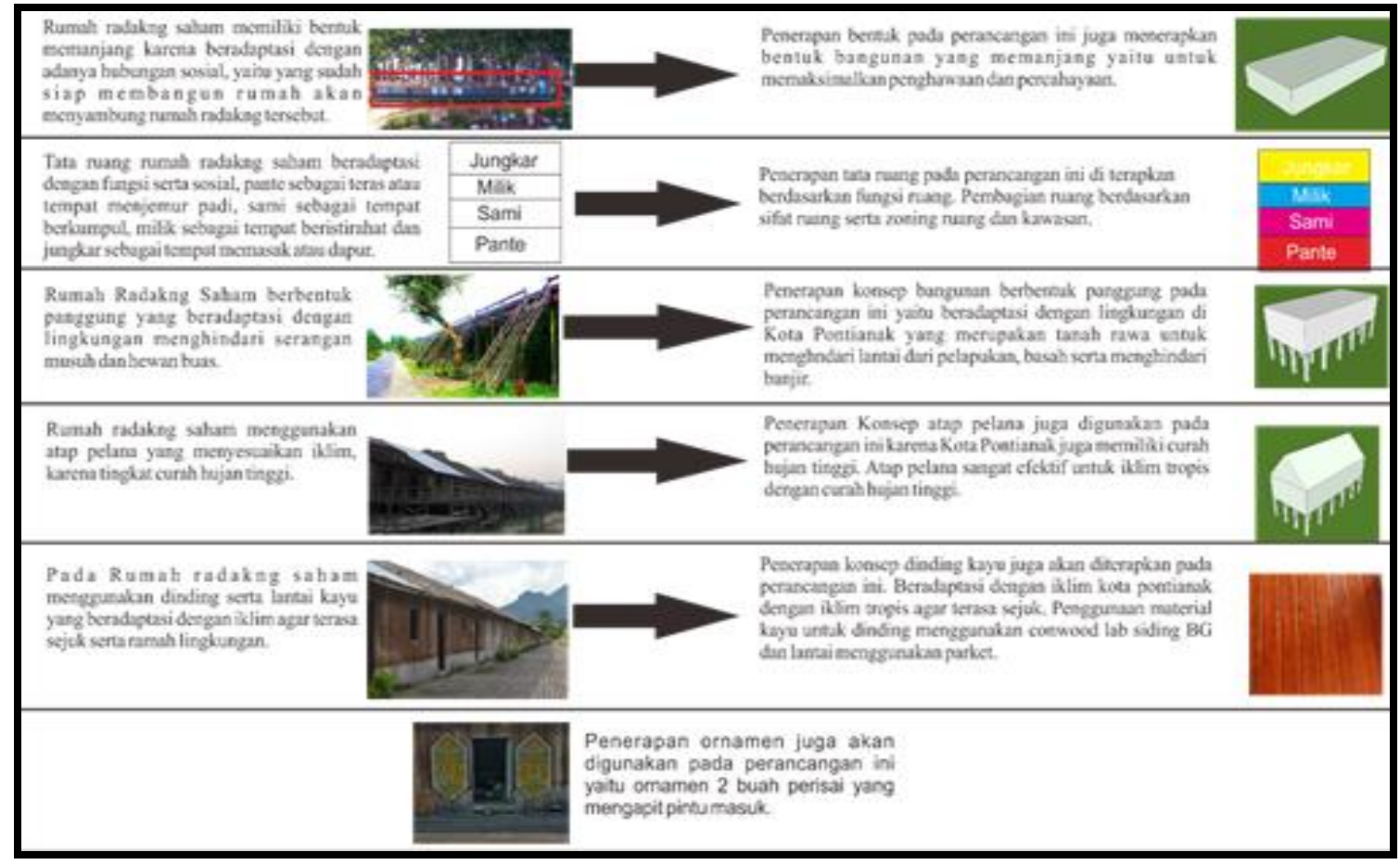

Gambar 8. Konsep Gubahan Bentuk

Sumber: Penulis, 2020

\section{Konsep Struktur}

Konsep struktur didapar berdasarkan analisis struktur. Struktur yang akan diterapkan terbagi menjadi dua yaitu stuktur bawah (sub structure) dan struktur atas (upper side super structure). Struktur bawah yaitu pondasi yang akan digunakan yaitu jenis pondasi tiang pancang pracetak, rangka menggunakan struktur rangka beton dan baja dan lantai menggunakan beton yang difinishing dengan keramik atau papan parket. Pada struktur atas yaitu struktur atap menggunakan rangka baja ringan. 


\section{Konsep Utilitas}

Konsep utilitas terdiri dari 5 variabel yang di dalamnya terdapat mekanisme jaringan air, jaringan listrik, tata udara, keamanan bangunan serta persampahan. Berkenaan dengan sistem jaringan air akan terbagi menjadi sistem jangan air bersih yang akan memanfaatkan sistem downfeed, sistem jaringan limbah padat, serta limbah cair. Jaringan listrik akan menggunakan jaringan listrik dari PLN serta disediakan pula sebuah genset sebagai antisipasi jika terjadi gangguan. Untuk sistem tata udara pada bangunan akan menggunakan sistem penghawaan buatan berupa jenis AC Split. Sedangkan untuk sistem keamanan bangunan yaitu penyediaan sprinkler, hydrant box dan lapangan, tangga darurat.

\section{Siteplan}

Siteplan Pusat Kesenian Dayak Kalimantan Barat di Kota Pontianak dirancang menyesuaikan hasil analisa dan konsep. Siteplan dibagi menyesuaikan dengan zonasi yang sudah di buat, yaitu zona publik, zona semi publik, zona semi privat, zona privat, dan zona servis. Zona publik terdiri dari area parkir pengunjung dan taman depan. Zona semi publik terdiri dari bangunan gedung pertunjukan \& galeri seni seta cafetaria \& toko souvenir. Zona semi privat terdiri dari bangunan gedung studio kesenian \& perpustakaan serta sekretariat sanggar seni. Zona privat terdiri dari parkiran pengunjung belajar kesenian, parkiran pengelola dan gedung pengelola. Zona servis terdiri dari area servis dan ruang MEE.

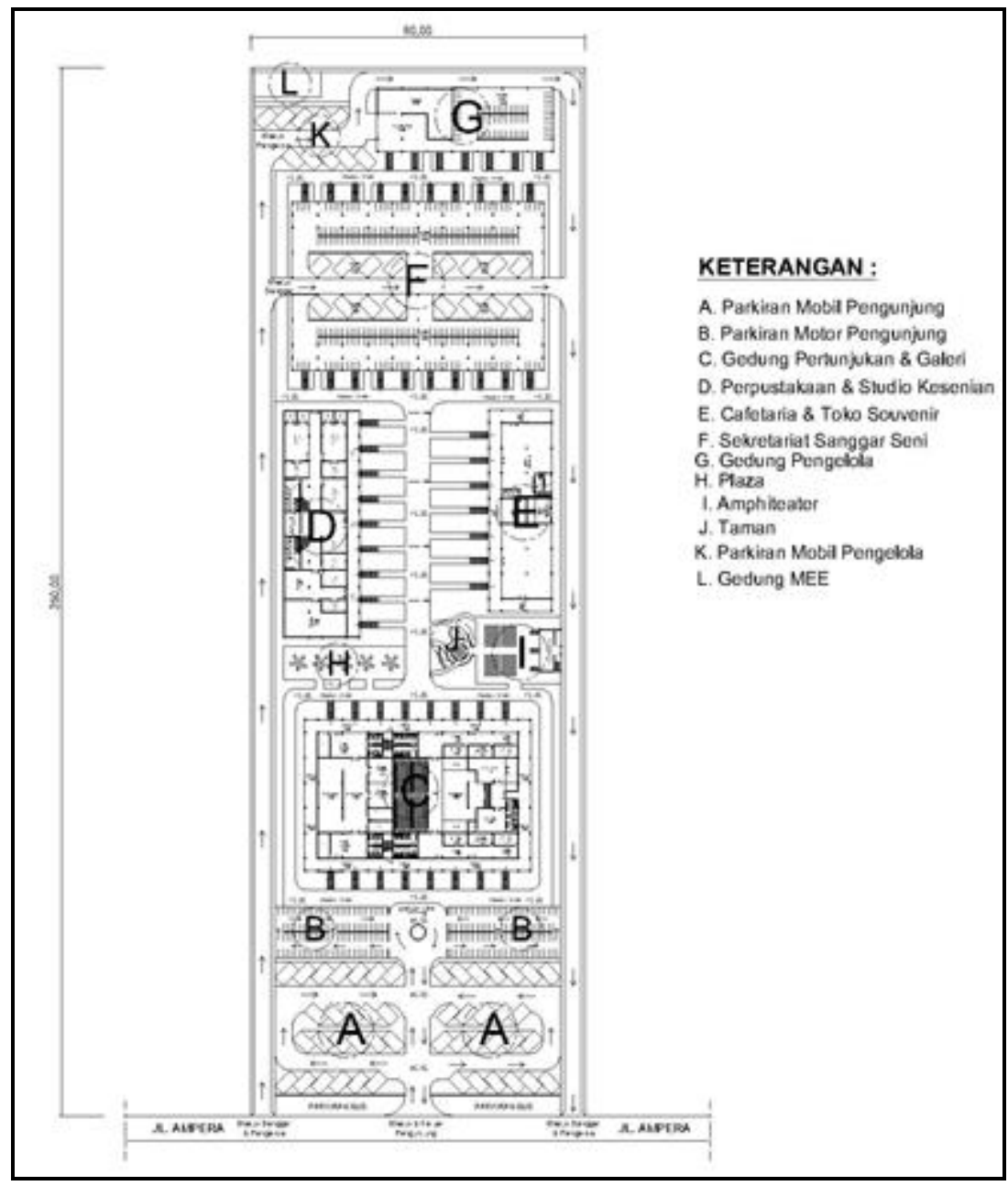

Gambar 9. Site Plan

Sumber: Penulis, 2020 


\section{Denah}

Massa bangunan pada Pusat Kesenian Dayak Kalimantan Barat di Kota Pontianak di bagi menjadi 5, gedung pertunjukan \& galeri seni, cafetaria \& toko souvenir, studio kesenian \& perpustakaan, sekretariat sanggar seni dan gedung pengelola. Pembagian massa menyesuaikan dengan pembagian fungsi bangunan. Massa bangunan di letakkan sesuai dengan zona masingmasing. Jumlah denah masing-masing bangunan berbeda sesuai kebutuhan pada fungsi bangunan. Berikut pembahasan dari denah bangunan pada Pusat Kesenian Dayak Kalimantan Barat Di Kota Pontianak.

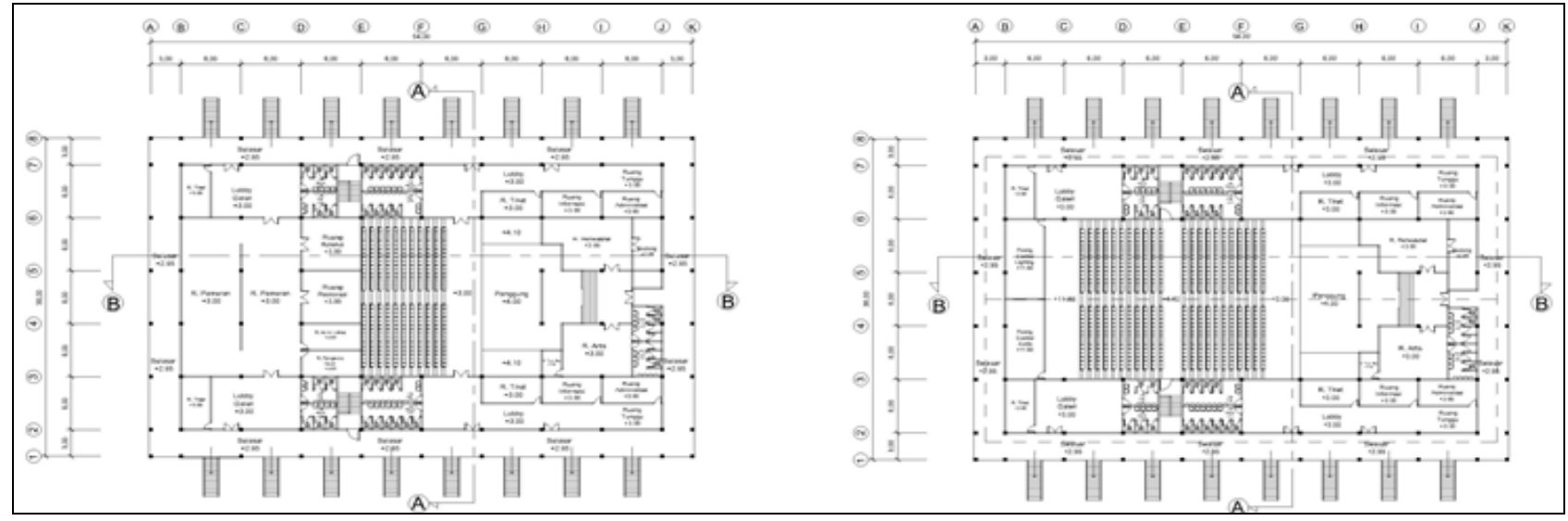

Gambar 10. Denah Gedung Pertunjukan \& Galeri Seni

Sumber: Penulis, 2020

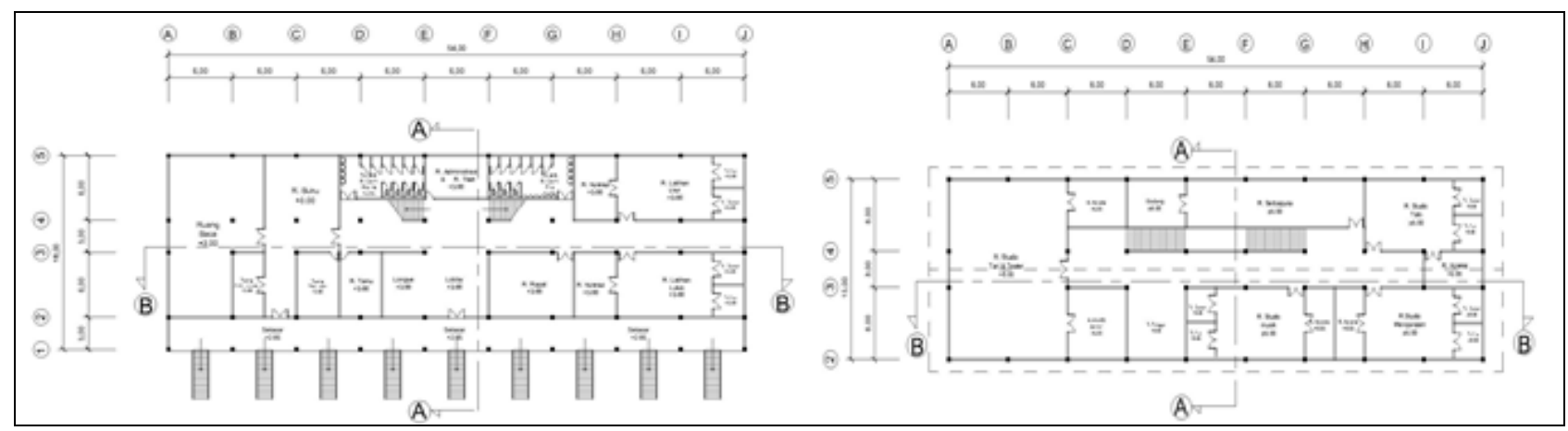

Gambar 11. Denah Studio Kesenian \& Perpustakaan

Sumber: Penulis, 2020

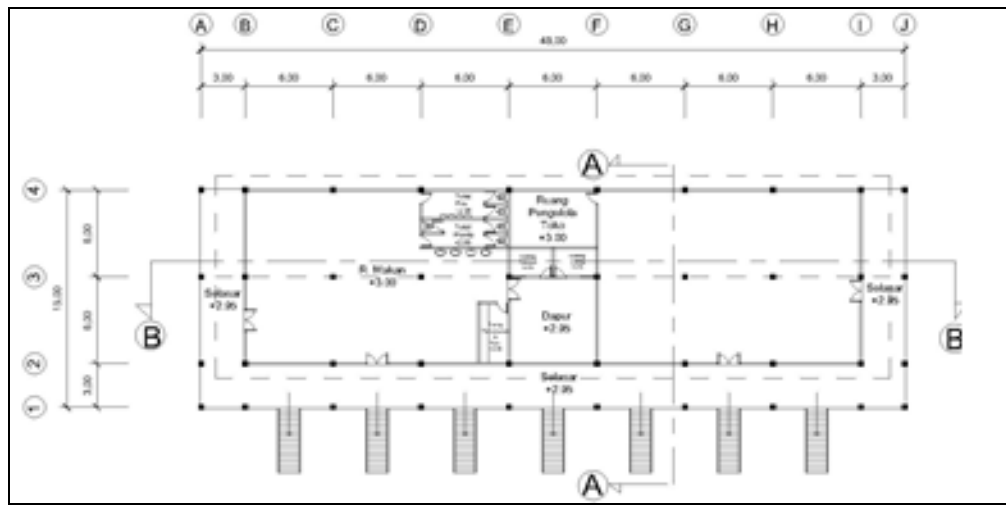

Gambar 12. Denah Cafetaria \& Toko Souvenir

Sumber: Penulis, 2020 


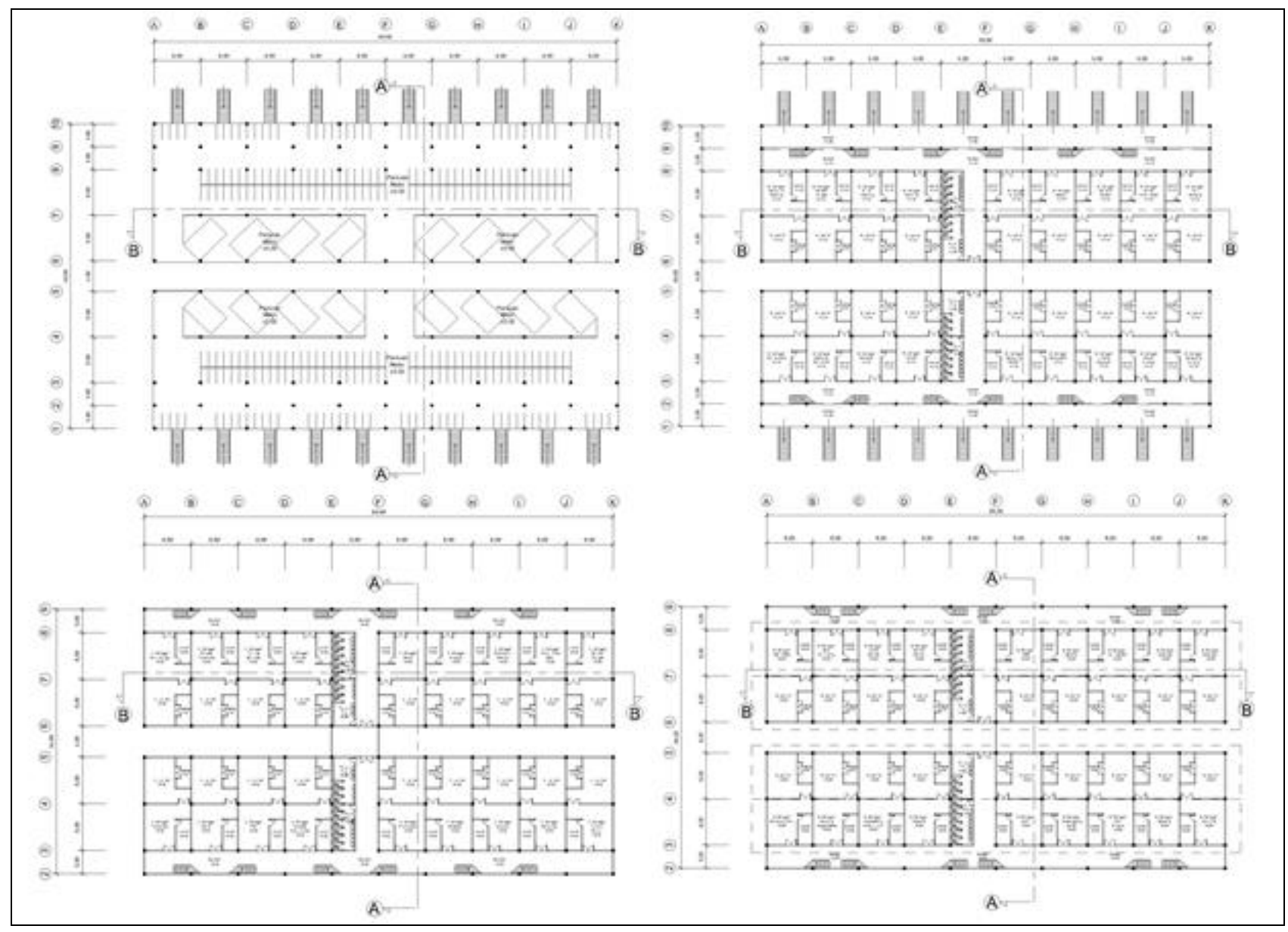

Gambar 13. Denah Sekretariat Sanggar Seni

Sumber: Penulis, 2020

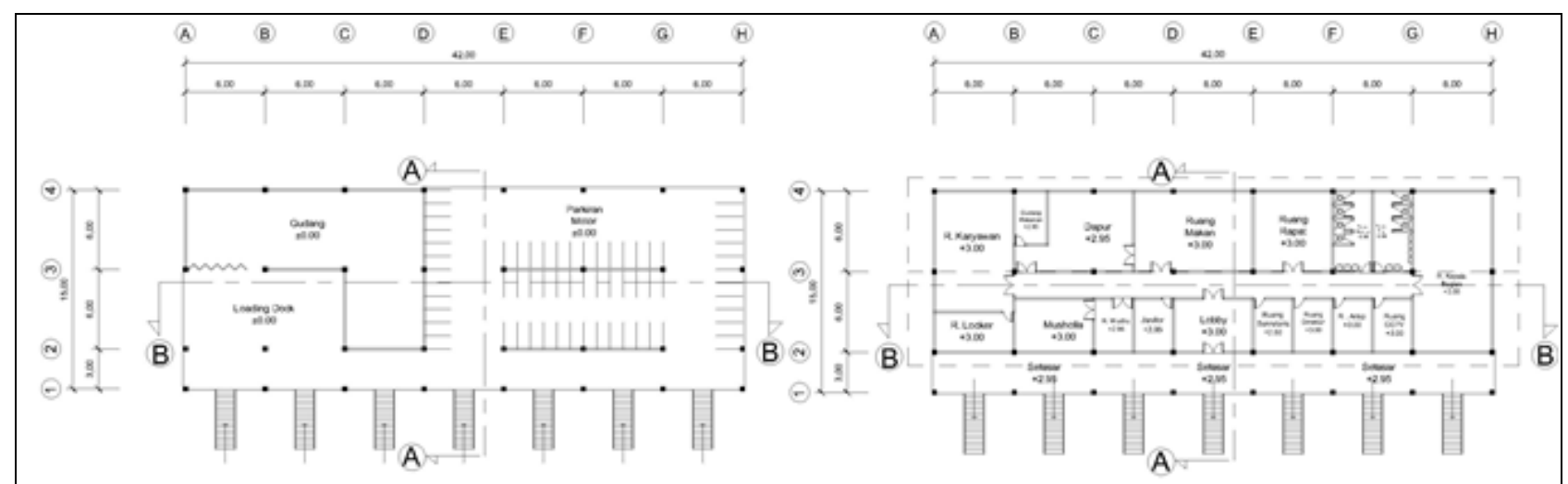

Gambar 14. Denah Gedung Pengelola

Sumber: Penulis, 2020

\section{Tampak}

Tampak tiap massa bangunan memiliki karakteristik yang sama. Bangunan dirancang dengan bentuk seperti rumah betang yang mengambil bentuk dari rumah radakng saham. Perancangan massa bangunan menghasilkan tampak setiap massa yang memiliki kemiripan berupa penggunaan material, yaitu material beton dan kayu. beton digunakan sebagai material penutup dinding. 


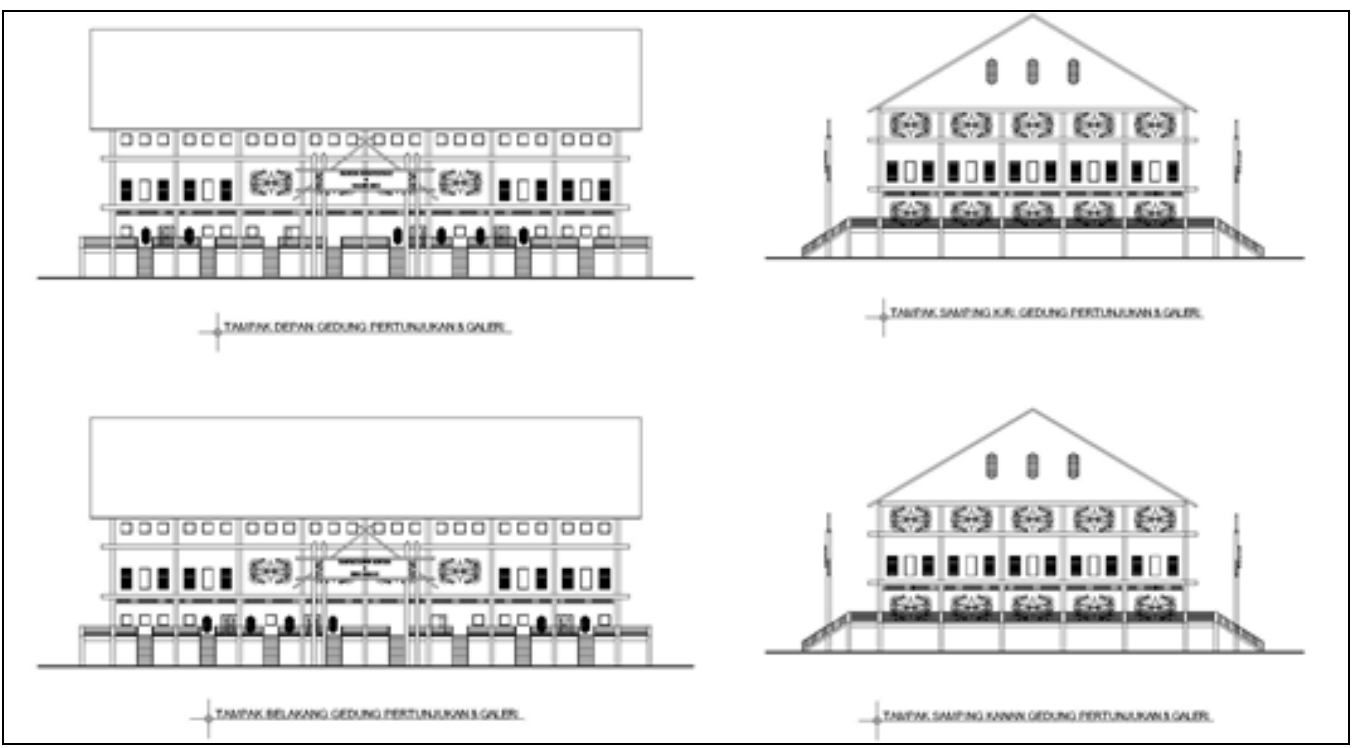

Gambar 15. Tampak Gedung Pertunjukan \& Galeri Seni Sumber: Penulis, 2020

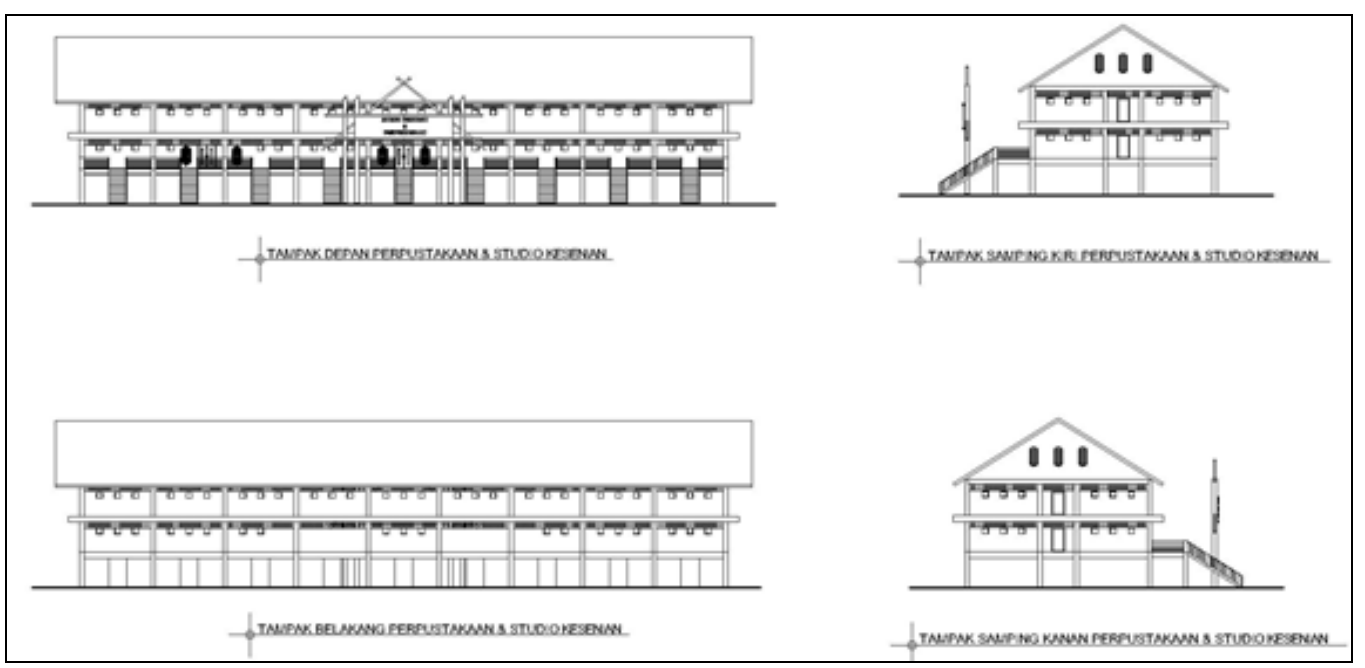

Gambar 16. Tampak Studio Kesenian \& Perpustakaan Sumber: Penulis, 2020

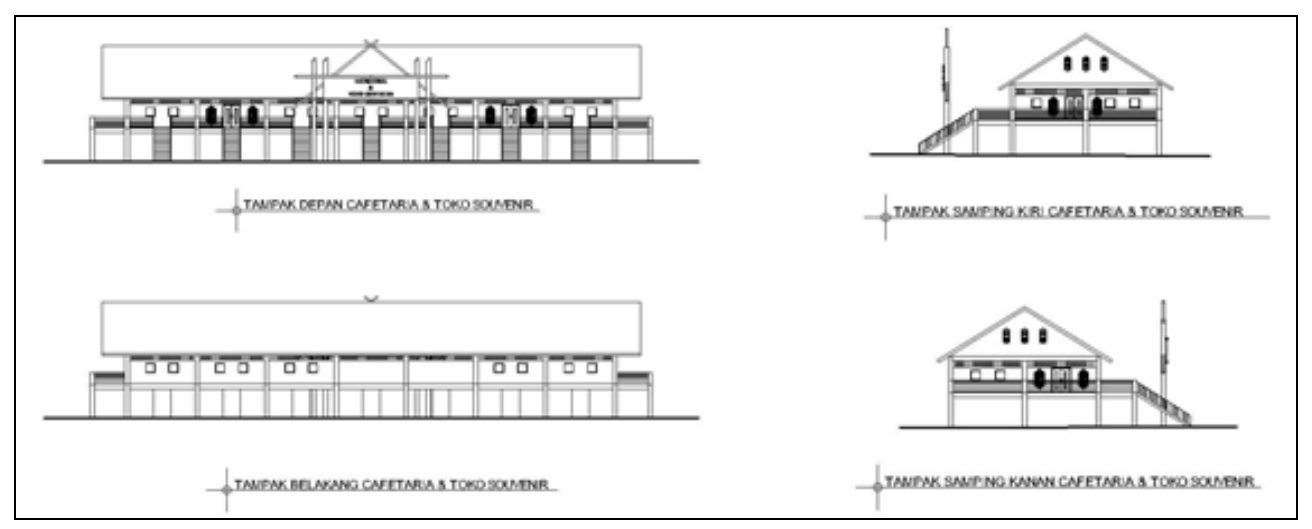

Gambar 17. Tampak Cafetaria \& Toko Souvenir Sumber: Penulis, 2020 


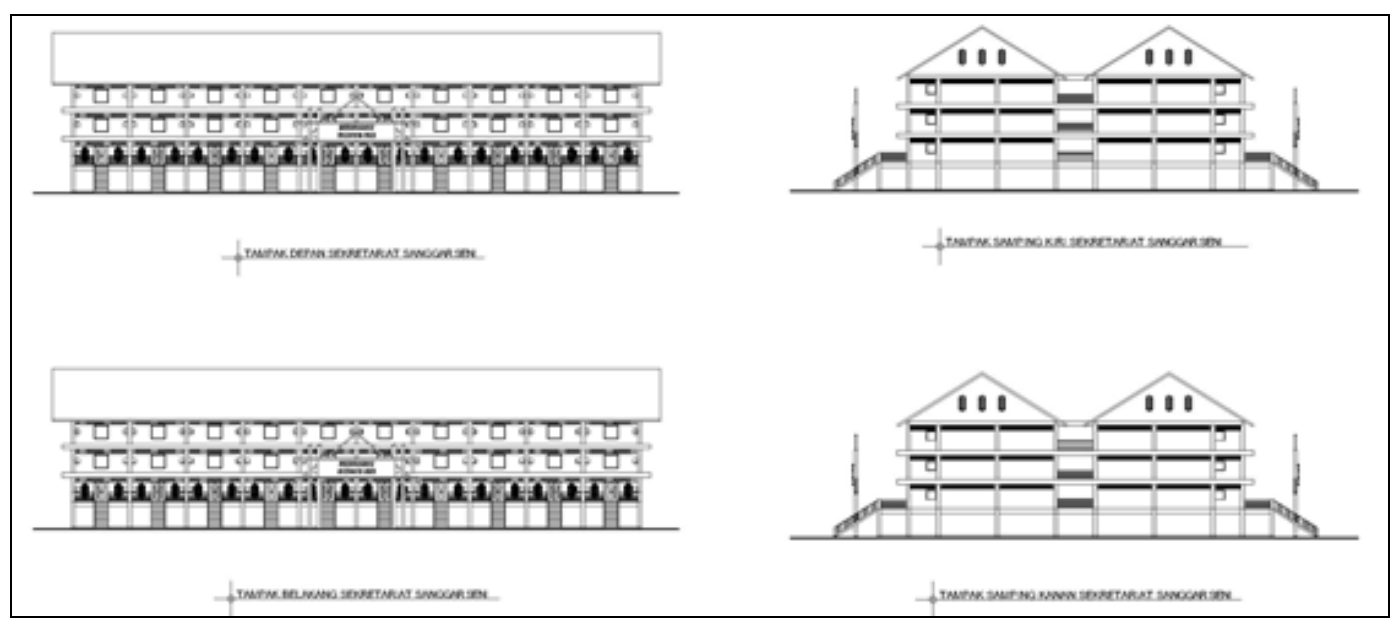

Gambar 18. Tampak Sekretariat Sanggar Seni Sumber: Penulis, 2020

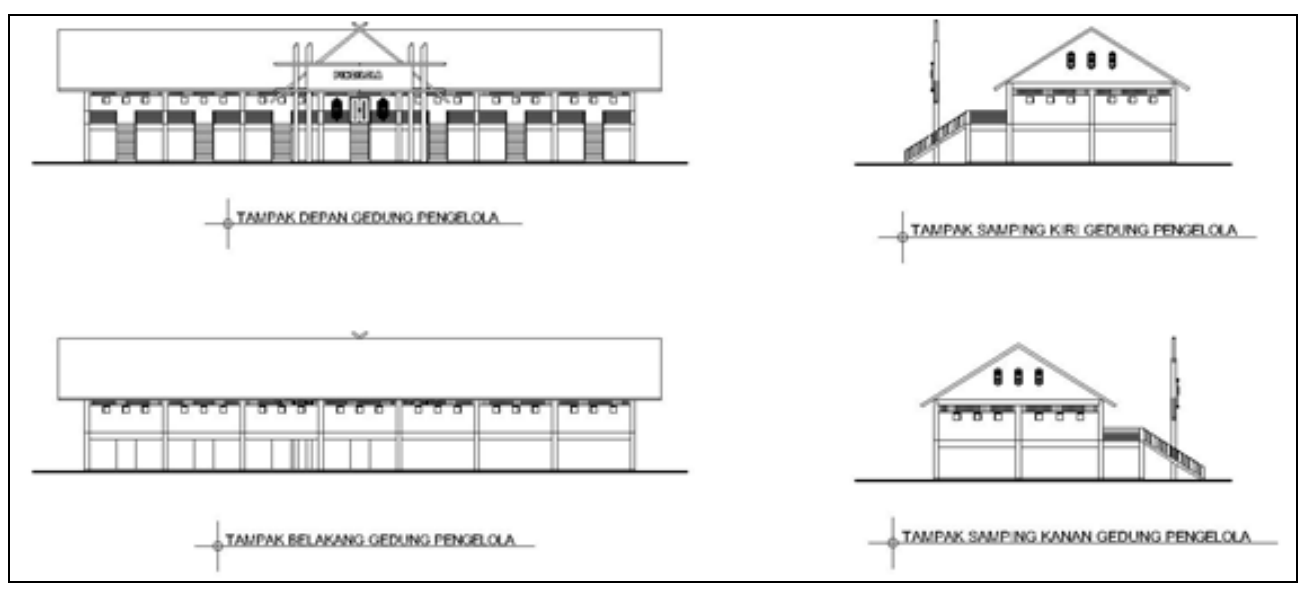

Gambar 19. Tampak Gedung Pengelola

Sumber: Penulis, 2020

\section{Potongan}

Potongan pada perancangan Pusat Kesenian Dayak Kalimantan Barat di Kota Pontianak menunjukkan sistem struktur pada bangunan dan kawasan. Bangunan menggunakan sistem pondasi titik dan pondasi tiang pancang mini pile. Masing-masing massa menggunakan sistem rangka beton bertulang. Material rangka atap yang digunakan pada bangunan adalah baja ringan dan penutup atap menggunakan eter.

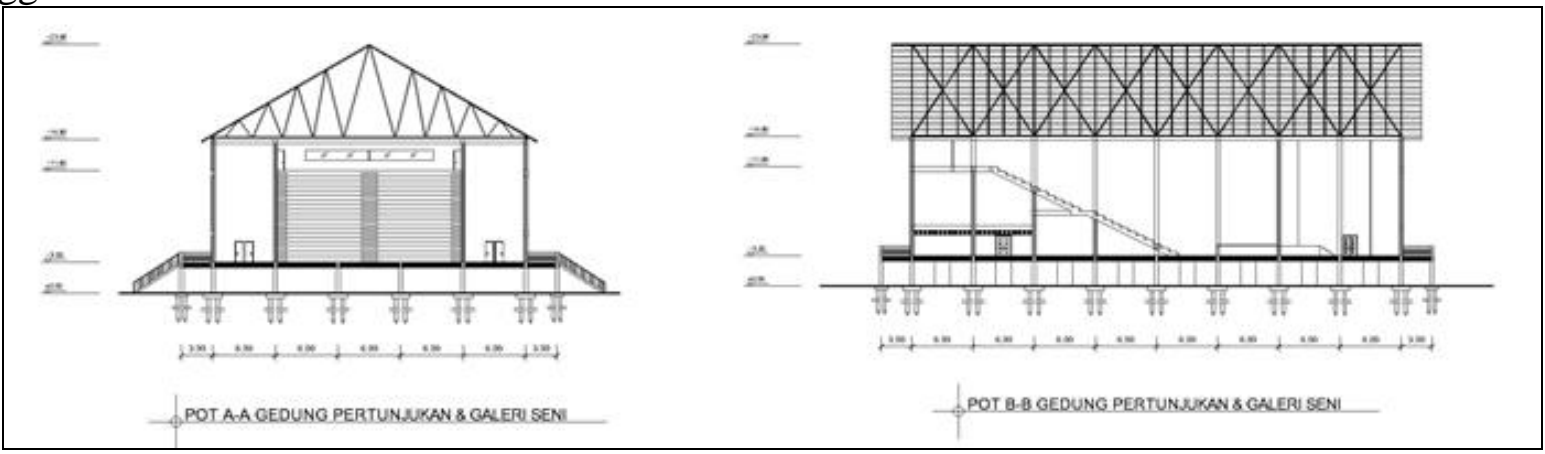

Gambar 20. Potongan Gedung Pertunjukan \& Galeri Seni

Sumber: Penulis, 2020 


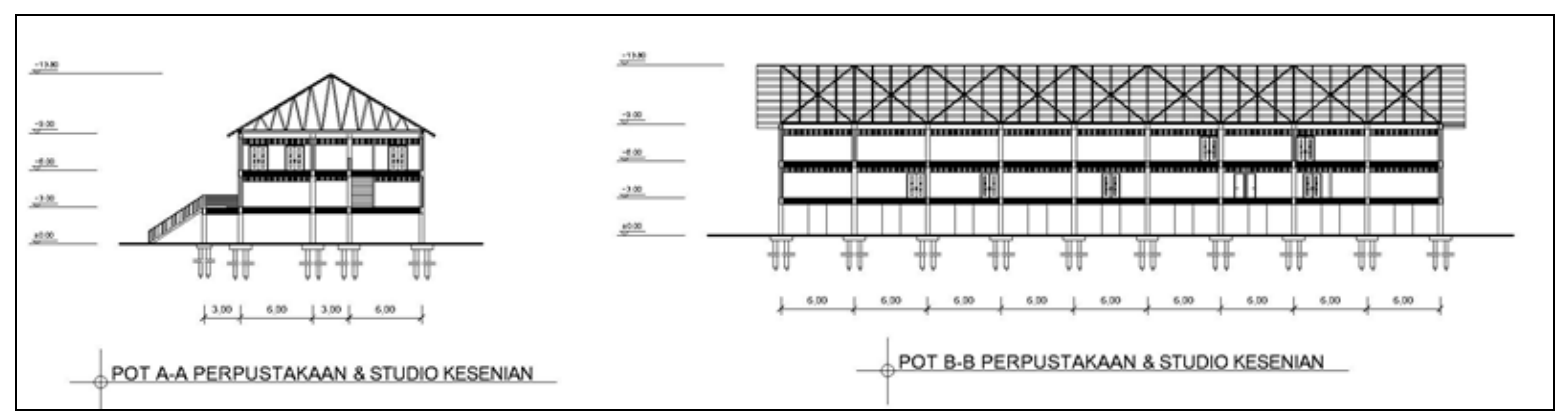

Gambar 21. Potongan Studio Kesenian \& Perpustakaan

Sumber: Penulis, 2020

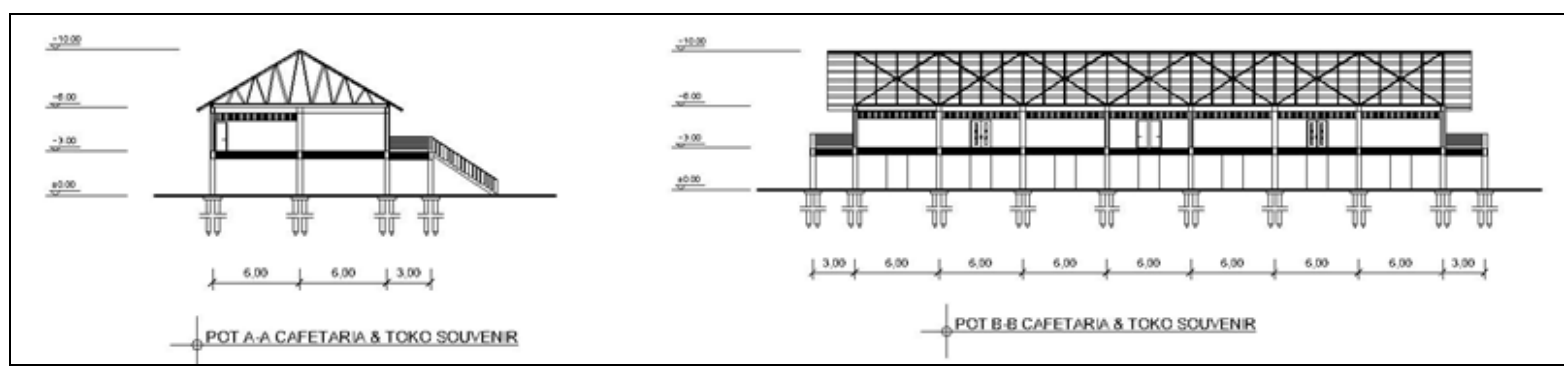

Gambar 22. Potongan Cafetaria \& Toko Souvenir

Sumber: Penulis, 2020

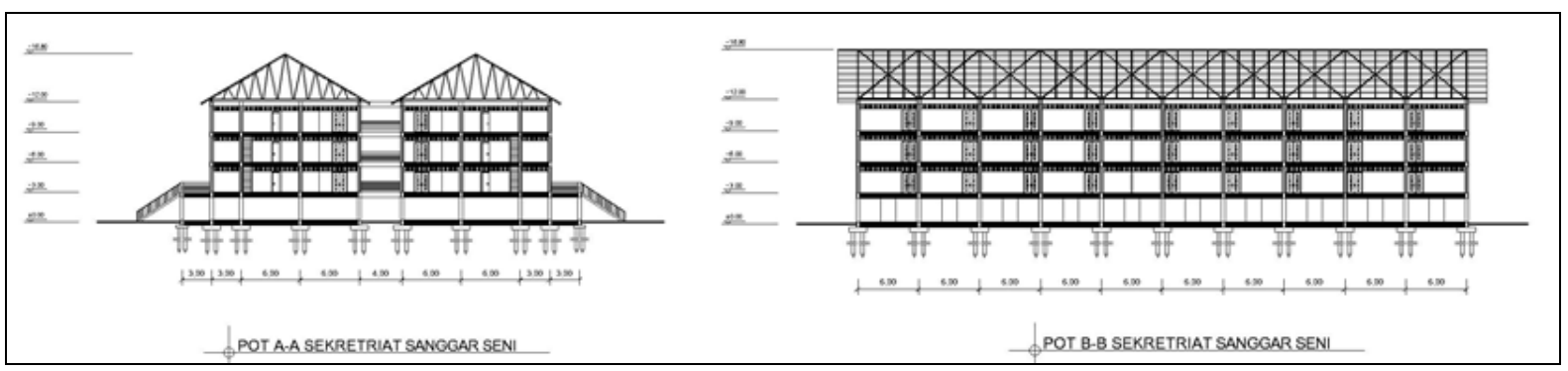

Gambar 23. Potongan Sekretariat Sanggar Seni

Sumber: Penulis, 2020

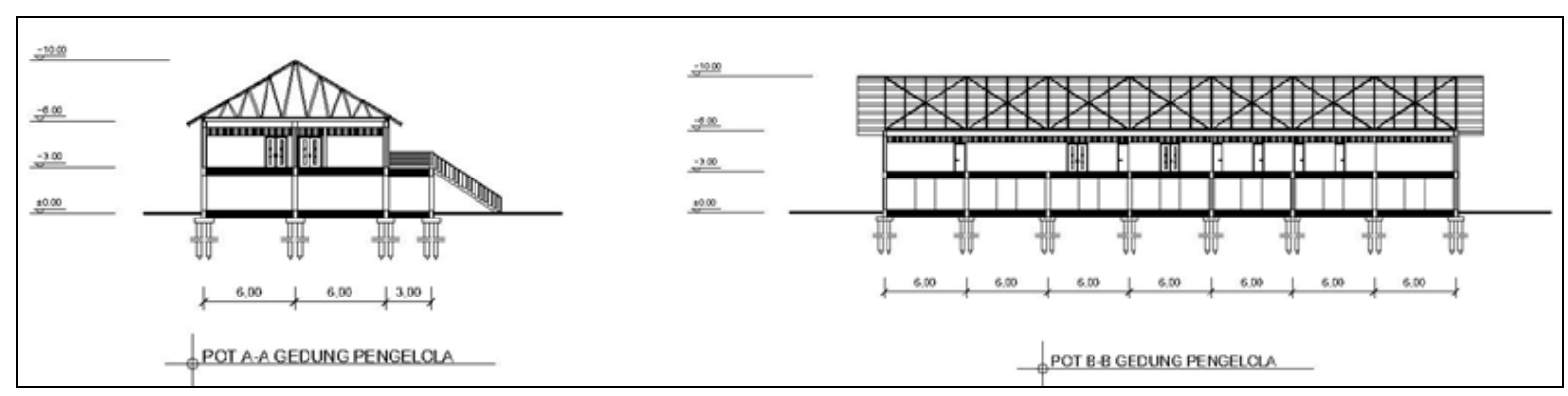

Gambar 24. Potongan Gedung Pengelola

Sumber: Penulis, 2020

\section{Suasana Ruang Luar}

Suasana eksterior adalah visualisasi dari kawasan Pusat Kesenian Dayak Kalimantan Barat di Kota Pontianak. Suasana eksterior memperlihatkan penerapan dari pendekatan arsitektur vernakular Dayak pada Pusat Kesenian Dayak Kalimantan Barat di Kota Pontianak, yaitu alam dan tradisional. Perancangan penghubung antar massa menggunakan elemen kayu dan vegetasi sebagai penerapan tema arsitektur tradisional Dayak. 


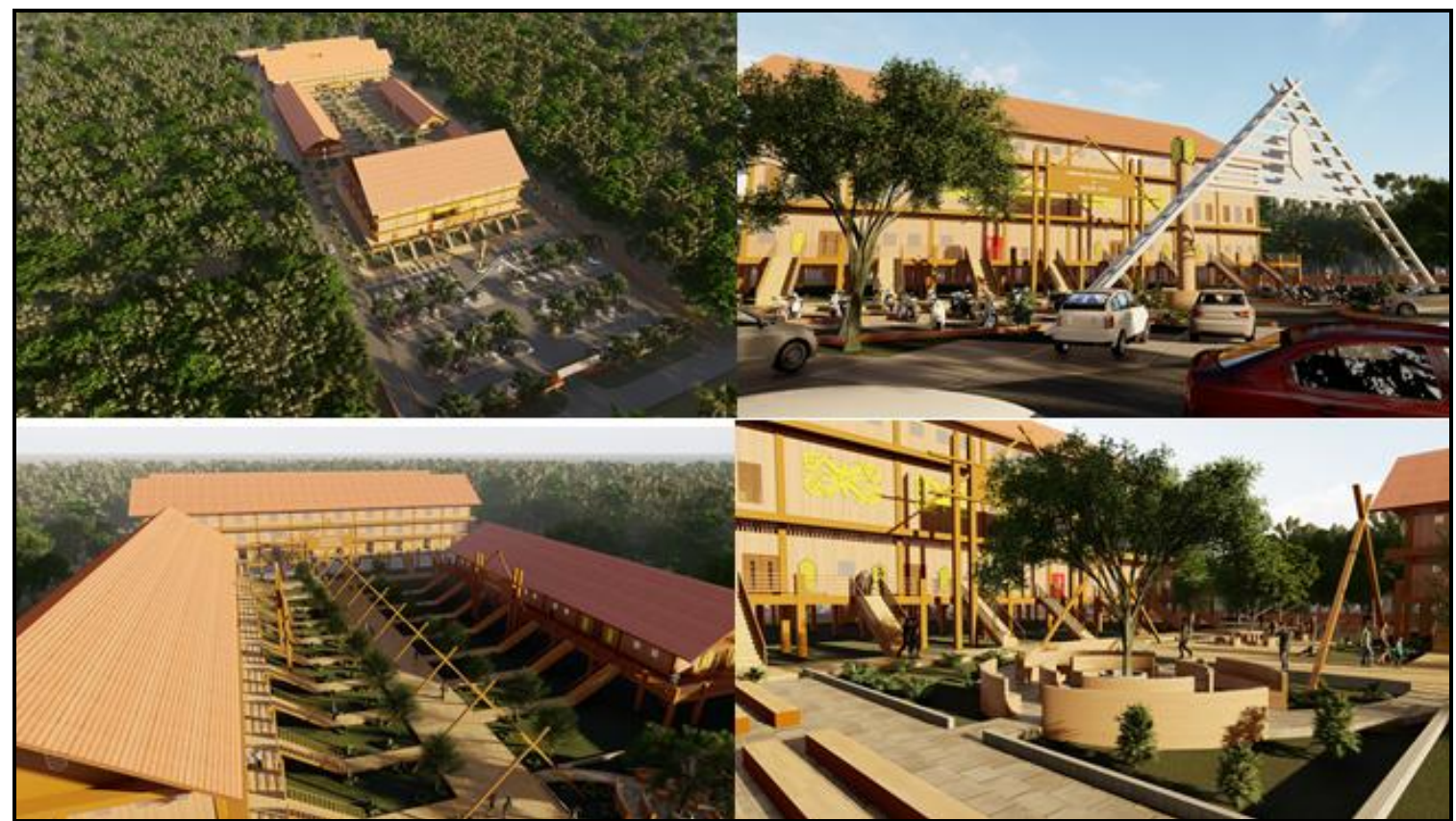

Gambar 25. Suasana Ruang Luar

Sumber: Penulis, 2020

\section{Suasana Ruang Dalam}

Berikut ini adalah gambar-gambar visualisasi interior pada perancangan Pusat Kesenian Dayak Kalimantan Barat di Kota Pontianak. Perancangan interior memadukan unsur-unsur ornament Dayak. Interior bangunan berfokus kepada penggunaan warna. Perancangan menggunakan warna coklat. Warna coklat dipilih agar ruangan tercipta suasana seperti kayu. Perancangan interior juga menggunakan ornament Dayak. Penggunaan ornamen Dayak bertujuan untuk memberikan tema arsitektur tradisional Dayak.

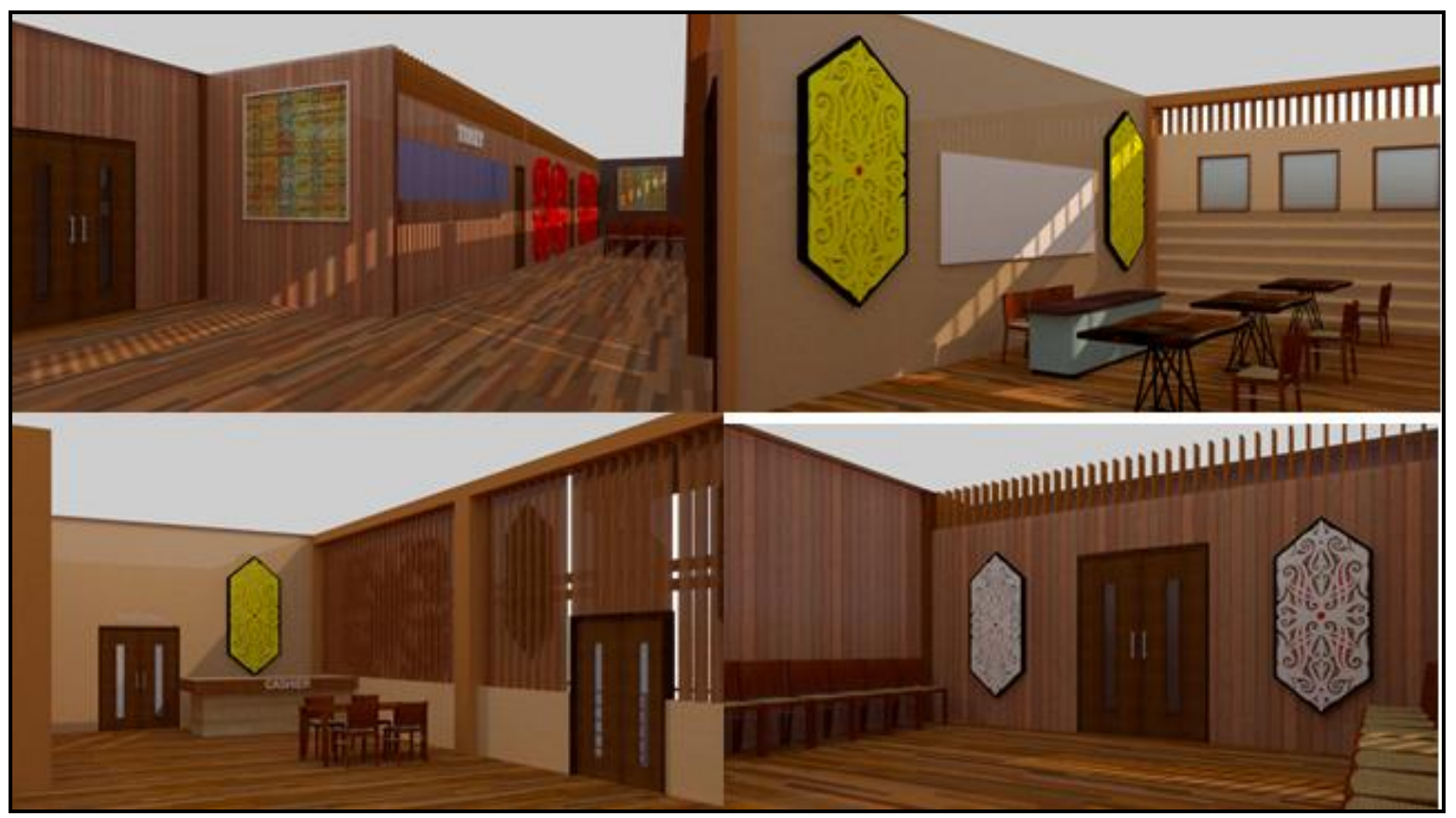

Gambar 26. Suasana Ruang Dalam

Sumber: Penulis, 2020 


\section{Kesimpulan}

Kesimpulan yang dapat ditarik dari perancangan Pusat Kesenian Dayak Kalimantan Barat di Kota Pontianak dengan tema arsitektur tradisional Dayak ini adalah bagaimana penerapan konsep tradisional Dayak dalam perancangan ini dapat memberikan sebuah tempat wisata baru yang bernuansa Dayak dan dapat menjadi sebuah pelestarian dari rumah Dayak. Melalui perancangan ini terdapat berbagai macam fasilitas kesenian yang dapat menampung kegiatan kesenian Dayak yang ada di Kalimantan Barat ini. Tentunya Pusat Kesenian Dayak Kalimantan Barat ini merupakan terobosan baru yang dapat meningkatkan niat masyarakat untuk belajar kesenian Dayak Kalimantan Barat dan dapat melestarikannya. Selain daripada itu dari masyarakat yang sebelumnya tidak memiliki akses atau belum masuk ke dalam dunia kesenian Dayak, dan dari perancangan ini semua kalangan dapat masuk ke dalam sanggar ataupun mengikuti workshop di dalam Pusat Kesenian Dayak Kalimantan Barat di Kota Pontianak ini.

\section{Ucapan Terima Kasih}

Ucapan terima kasih kepada Bapak Dr. Uray Fery Andi, S.T., M.T., selaku dosen pembimbing utama; Bapak Ir. Rudiyono, M.T. selaku dosen pembimbing pendamping; Bapak Syaiful Muazir, S.T., M.T., Ph.D., selaku dosen penguji utama; Bapak Hamdil Khaliesh, S.T., M.T., selaku dosen penguji pendamping; Bapak Tri Wibowo Caesariadi, S.T., M.T., selaku dosen pembimbing akademik; serta kepada seluruh dosen dan staf Program Studi Arsitektur Universitas Tanjungpura yang telah memberikan ilmu yang bermanfaat selama ini.

\section{Daftar Acuan}

Alloy, S. (2008). Mozaik Dayak Keberagaman Subsuku dan Bahasa Dayak Di Kalimantan Barat. Pontianak: Institut Dayakologi

Lontaan, J.U. (1975). Sejarah Hukum Dan Adat dan Adat Istiadat Kalimantan Barat, pemda tingkat I Kalbar. Pontianak: Pemda Tingkat 1 Kalimantan Barat.

Maryani, M. (2018). Pedoman Pekan Gawai Dayak Ke-33 Kota Pontianak. Pontianak: Sekretariat Bersama Kesenian Dayak Kalimantan Barat

Riwut, T. (1979). Kalimantan Membangun. Jakarta: Jayakarta Agung Offset

Nuraini, C., Sudrajat, I. (2010). Metode Perancangan Arsitektur. Bandung: Karya Putra Darwati 